\title{
THE EFFECT OF AUTONOMIC GANGLIONIC BLOCKADE UPON SERUM FREE FATTY ACID LEVELS IN MAN *
}

\author{
By MORTON D. BOGDONOFF, ARNOLD M. WEISSLER AND \\ FRANK L. MERRITT \\ (From the Departments of Medicine, Duke University Medical Center and Durham Veterans
Administration Hospital, Durham, N. C.)
}

(Submitted for publication December 28, 1959; accepted February 25, 1960)

Epinephrine and norepinephrine injection into man is followed by a rise in free fatty acid (FFA) concentration of the serum $(1,2)$. Incubation of adipose tissue in vitro with these catechol amines results in an accumulation of FFA in the media suggesting that norepinpehrine and epinephrine possess the property of enhancing lipolysis $(3,4)$. Psychologically meaningful experiences which might be expected to stimulate epinephrine and norepinephrine secretion, such as discussions of anxiety-producing topics (5), potential puncture by a large needle (6) or taking a crucial scholastic examination (7), are followed by increases in serum FFA level. These observations suggest that in man the sympathetic portion of the autonomic nervous system may play a regulatory role in the control of serum FFA level. The experiments reported here were designed to evaluate such a potential contribution of the autonomic nervous system.

\section{METHOD}

Twelve subjects were studied in the morning following an overnight fast (total fasting time, 10 to 12 hours). The subjects arrived at the laboratory, were instructed in the procedure that was to follow, and then reclined on the bed. An indwelling Cournand needle was placed in a brachial artery, and the arterial pressure was recorded continuously by a strain-gauge manometer, using a direct-writing Sanborn recorder. Two venipunctures were then performed (one in each forearm) with indwelling needles placed there. All needle sites were locally anesthetized prior to needle implantation. Total time for all needle insertions was usually 10 minutes. If any undue difficulty was encountered in inserting the needles, the experiment was discontinued. A slow infusion of normal saline ( 0.25 to $0.5 \mathrm{ml}$ per minute) was started in one vein. All conversation was gradually brought to a close, the lights dimmed, and the subject allowed to "relax" as much as possible. Samples were

* Supported in part by the Irwin Strasburger Memorial Medical Foundation and in part by The Center for the Study of Aging, Public Health Service, Grants (M 2109) and (H 3582). then drawn every 15 minutes from a venous needle, the initial sample being drawn 15 minutes after all preparatory procedures were completed. The first subjects studied (Group 1) consisted of either student volunteers or ambulatory patients who were in the hospital for acute infectious disease, resolving at the time of the study, or for diagnostic studies of a "functional disorder." None of the patients was manifestly ill at the time of the study. The second subjects (Group 2) consisted of 6 ambulatory patients, comparably classified to the patients of Group 1. The age range of this group, however, was somewhat older, and in several members the intensity of psychological disturbance underlying the "functional" disorder appeared to be more intense.

The experimental run was divided into three 60-minute periods: the initial observation or "pre-infusion" period, the "infusion" period, and the "post-infusion" period. During the infusion period, Group 1 received 0.9 per cent saline at a rate of 1 to $2 \mathrm{ml}$ per minute, and Group 2 received trimethaphan camphorsulfonate (Arfonad ${ }^{1}$ ), a rapidly metabolized ganglionic blocking agent, at a rate of 2 to $4 \mathrm{mg}$ per minute $(500 \mathrm{mg}$ in $250 \mathrm{ml}$ of 0.9 per cent saline; 1 to $2 \mathrm{ml}$ per minute). All infusions were controlled by a stopcock on the tubing and judged by the number of drops falling through the tubing per minute.

Throughout the procedure, there was as little conversation as possible in the laboratory. References to health, the basis for hospitalization or personal matters were strictly avoided. Reassurance about the satisfactory quality of the study was made throughout the morning, and the subjects were asked about their comfort by the attending nurse. Since the total duration of the experiment was 3 hours, fatigue and restlessness were often observed, and verbal mention of it by the subjects was encouraged and allowed. No attempt was made to avoid mention of the discomfort, and the subjects were asked to request attendance if needed (changing the pillow, altering the bed position, adjusting room temperature and so forth). During the infusion period the subject was periodically asked to perform a 5-second Valsalva maneuver. Absence of the post-Valsalva blood pressure overshoot, as well as persistent hypotension and tachycardia, was considered to be evidence of existing ganglionic blockade. During the infusion of the gang-

1 Arfonad Camphorsulfonate (trimethaphan camphorsulfonate). 
lionic blocking substance the subjects reported a sensation of dry mouth and generalized body warmth, and several subjects experienced a sensation of relaxation. FFA levels were measured by the method of Dole (1), and blood sugar levels were determined by the method of Nelson (8).

Although no extensive post-study psychological tests were performed, notes were kept on the general status of arousal of the subject as indicated by his comments during the procedure and his general motor behavior. The term arousal refers to the degree of alertness and the individual's apparent awareness of the events occurring about him. Evidence of anxiety, overt fear or any other intense affect síate, such as hostility, would all contribute to increasing the observer's rating of arousal. A specific statement was then made regarding the assessment of arousal in terms of "minimal," "moderate," or "marked," and this evaluation was made for each period of the study and recorded independently of any knowledge of the physiological data, including the blood pressure and pulse. One observer (MDB) made the evaluation for all experiments.

\section{RESULTS}

Saline infusions. In all six subjects of Group 1, serum FFA levels increased during the course of the morning (Figure 1). In Subjects 1 and 2 there were minimal changes (mean $=+85$ and $+100 \mu \mathrm{Eq}$ per L). In Subjects 3 and 6 there were minimal changes during periods I and II and then sharp rises in period III. In Subjects 4 and 5 there were consistent marked rises throughout. During the course of the morning blood pressure levels increased in all subjects, being greatest in Subjects 2, 4 and 5, and minimal in Subjects 1, 3 and 6. Heart rates did not appreciably change (Table I). In five of the six subjects, blood glucose levels varied no more than $\pm 5 \mathrm{mg}$ per $100 \mathrm{ml}$ about a mean value for each individual. In Subject 6, however, there was a decline of $22 \mathrm{mg}$ per $100 \mathrm{ml}$ during the first 2.5 hours of the study, with a final rise to the initial level at the end of the study.

The independent arousal assessment made for the individual subjects varied from period to period. Subjects 1 and 2 were rated as either "minimally" or "not at all" aroused, both having slept through most of the procedure. Subject 3 was rated as "calm" and "usually sleeping" during periods I and II (minimal arousal) but during period III was considered to be "moderately" aroused. Subjects 4 and 5 were considered to be "moderately" aroused throughout the study. Subject 6 seemed "moderately" aroused on entry, then minimally so during period II, with final restlessness and "moderate" arousal during period III.

Arfonad infusions. During period I, the FFA levels in Subjects 7, 8 and 9 were lower and varied less than in Subjects 10, 11 and 12. During the Arfonad infusions, FFA levels fell in Sub-

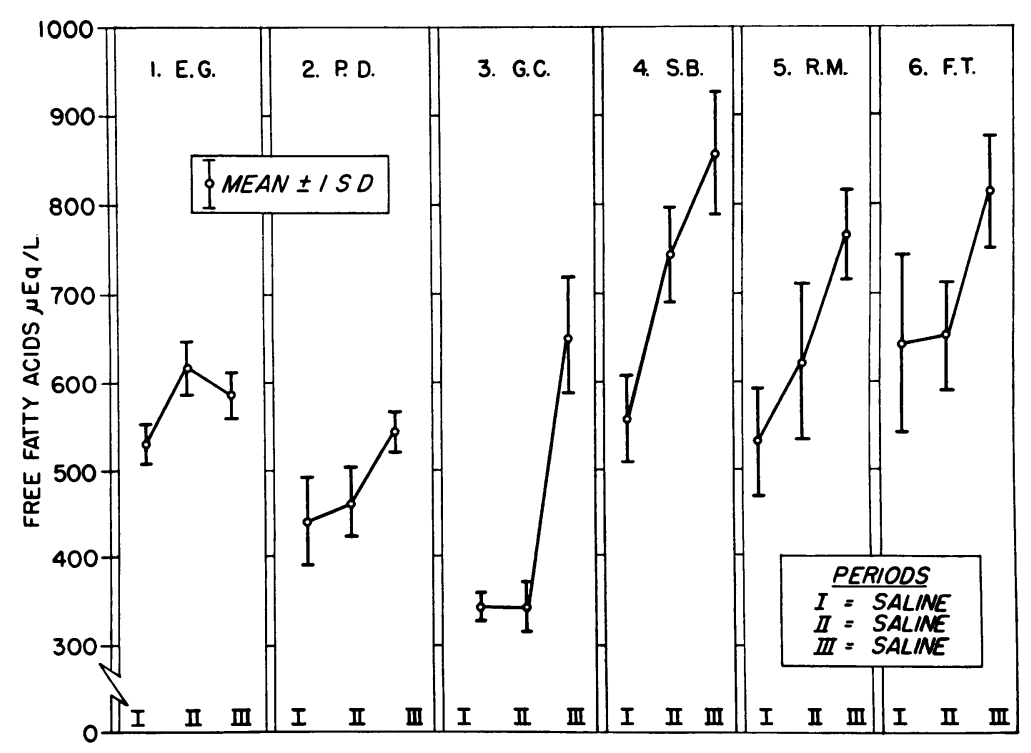

Fig. 1. Free fatty aCid Levels in Six subjects ReCeiving Saline infuSIONS THROUGHOUT ALL THREE PERIODS OF OBSERVATION. 
TABLE I

Arterial blood pressure and heart rate before, during and after infusion of saline or Arfonad

\begin{tabular}{|c|c|c|c|c|c|c|c|c|c|c|c|c|c|c|c|}
\hline \multirow{2}{*}{\multicolumn{2}{|c|}{ Subject }} & \multirow{2}{*}{\multicolumn{2}{|c|}{ Age Sex }} & \multicolumn{4}{|c|}{ Pre-infusion, minutes } & \multicolumn{4}{|c|}{ Infusion, minutes } & \multicolumn{4}{|c|}{ Post-infusion, minutes } \\
\hline & & & & \multicolumn{4}{|c|}{ Saline } & \multicolumn{4}{|c|}{${ }^{30}$ Saline ${ }^{45}$} & \multicolumn{4}{|c|}{ Saline } \\
\hline 1 & E. G. & 24 & $\mathbf{F}$ & \multirow{6}{*}{\multicolumn{2}{|c|}{$\begin{array}{c}120 / 80 \\
54 \\
140 / 90 \\
64 \\
98 / 56 \\
68 \\
110 / 66 \\
58 \\
136 / 80 \\
74 \\
103 / 65 \\
74\end{array}$}} & $\underset{54}{120 / 80}$ & $116 / 70$ & \multirow{6}{*}{$\begin{array}{c}118 / 80 \\
80 \\
142 / 88 \\
64 \\
99 / 55 \\
60 \\
129 / 75 \\
66 \\
135 / 88 \\
70 \\
108 / 68 \\
72\end{array}$} & \multirow{6}{*}{$\begin{array}{c}120 / 82 \\
52 \\
132 / 84 \\
60 \\
107 / 65 \\
62 \\
120 / 66 \\
56 \\
150 / 85 \\
66 \\
110 / 69 \\
66\end{array}$} & \multirow{6}{*}{$\begin{array}{c}122 / 80 \\
60 \\
136 / 86 \\
60 \\
114 / 62 \\
58 \\
120 / 72 \\
56 \\
150 / 84 \\
68 \\
114 / 67 \\
64\end{array}$} & \multirow{6}{*}{$\begin{array}{c}124 / 82 \\
54 \\
138 / 90 \\
56 \\
122 / 70 \\
58 \\
122 / 74 \\
58 \\
140 / 90 \\
66 \\
113 / 67 \\
74\end{array}$} & \multirow{6}{*}{$\begin{array}{c}118 / 80 \\
144 / 92 \\
56 \\
125 / 70 \\
56 \\
126 / 76 \\
72 \\
152 / 87 \\
62 \\
108 / 67 \\
84\end{array}$} & \multirow{6}{*}{$\begin{array}{c}118 / 75 \\
140 / 90 \\
56 \\
125 / 70 \\
58 \\
128 / 72 \\
62 \\
160 / 90 \\
64 \\
108 / 66 \\
68\end{array}$} & \multirow{6}{*}{$\begin{array}{c}122 / 84 \\
54 \\
142 / 88 \\
56 \\
123 / 71 \\
56 \\
132 / 75 \\
58 \\
166 / 92 \\
74 \\
111 / 69 \\
84\end{array}$} & \multirow{6}{*}{$\begin{array}{c}124 / 84 \\
52 \\
140 / 86 \\
56 \\
120 / 68 \\
62 \\
132 / 80 \\
64 \\
166 / 96 \\
70 \\
112 / 70 \\
82\end{array}$} \\
\hline 2 & P. D. & 25 & $\mathbf{M}$ & & & $\begin{array}{c}126 / 80 \\
58\end{array}$ & $130 / 82$ & & & & & & & & \\
\hline 3 & G. C. & 25 & $\mathbf{M}$ & & & $\begin{array}{l}97 / 56 \\
68\end{array}$ & & & & & & & & & \\
\hline 4 & S. B. & 21 & $\mathbf{M}$ & & & $\begin{array}{c}115 / 78 \\
70\end{array}$ & $\begin{array}{c}117 / 67 \\
54\end{array}$ & & & & & & & & \\
\hline 5 & R. M. & 24 & $\mathbf{M}$ & & & $\begin{array}{c}136 / 80 \\
74\end{array}$ & $\begin{array}{c}136 / 80 \\
74\end{array}$ & & & & & & & & \\
\hline 6 & F. T. & 24 & $\mathbf{M}$ & & & $\begin{array}{c}105 / 66 \\
72\end{array}$ & $\begin{array}{c}108 / 68 \\
68\end{array}$ & & & & & & & & \\
\hline & & & & \multicolumn{4}{|c|}{ Saline } & \multicolumn{4}{|c|}{ Arfonad } & \multicolumn{4}{|c|}{ Saline } \\
\hline 7 & S. A. & 25 & $\mathbf{M}$ & & $100 / 52$ & $100 / 52$ & $106 / 57$ & $96 / 57$ & $80 / 52$ & $88 / 55$ & $84 / 55$ & $96 / 60$ & $96 / 62$ & $105 / 60$ & $105 / 60$ \\
\hline 8 & J. B. & 42 & $\mathbf{M}$ & & $\begin{array}{c}50 \\
129 / 75 \\
68\end{array}$ & $\begin{array}{c}60 \\
129 / 75 \\
68\end{array}$ & $\begin{array}{c}58 \\
135 / 82 \\
74\end{array}$ & $\begin{array}{c}82 \\
117 / 75 \\
92\end{array}$ & $\begin{array}{c}90 \\
76 / 49 \\
88\end{array}$ & $\begin{array}{c}92 \\
63 / 43 \\
84\end{array}$ & $\begin{array}{c}72 \\
73 / 44 \\
82\end{array}$ & $\begin{array}{c}72 \\
75 / 45 \\
88\end{array}$ & $\begin{array}{c}72 \\
102 / 65 \\
90\end{array}$ & $\begin{array}{c}60 \\
118 / 73 \\
84\end{array}$ & $\begin{array}{c}54 \\
125 / 82 \\
78\end{array}$ \\
\hline 9 & B. $\mathbf{R}$. & 21 & $\mathbf{M}$ & $\begin{array}{c}104 / 70 \\
80\end{array}$ & $\begin{array}{c}104 / 68 \\
80\end{array}$ & $\begin{array}{c}104 / 70 \\
80\end{array}$ & $\begin{array}{c}104 / 66 \\
80\end{array}$ & $\begin{array}{c}74 / 54 \\
90\end{array}$ & $\begin{array}{c}70 / 52 \\
100\end{array}$ & $\begin{array}{c}76 / 50 \\
96\end{array}$ & $\begin{array}{c}78 / 56 \\
96\end{array}$ & $\begin{array}{c}102 / 70 \\
80\end{array}$ & $\begin{array}{l}98 / 70 \\
72\end{array}$ & $\begin{array}{c}98 / 68 \\
76\end{array}$ & $\begin{array}{c}104 / 70 \\
72\end{array}$ \\
\hline 10 & M. P. & 36 & $\mathbf{F}$ & $\begin{array}{c}118 / 80 \\
72\end{array}$ & $\begin{array}{c}124 / 78 \\
70\end{array}$ & $\begin{array}{c}118 / 80 \\
68\end{array}$ & $\begin{array}{c}120 / 80 \\
64\end{array}$ & $\begin{array}{l}98 / 70 \\
104\end{array}$ & $\begin{array}{l}94 / 70 \\
100\end{array}$ & $\begin{array}{l}90 / 63 \\
90\end{array}$ & $\begin{array}{l}92 / 66 \\
92\end{array}$ & $\begin{array}{c}116 / 78 \\
88\end{array}$ & $\begin{array}{c}114 / 78 \\
72\end{array}$ & $\begin{array}{c}122 / 80 \\
68\end{array}$ & $\begin{array}{c}130 / 80 \\
68\end{array}$ \\
\hline 11 & M. S. & 36 & $\mathbf{F}$ & $\begin{array}{c}110 / 68 \\
80 .\end{array}$ & $\begin{array}{c}104 / 70 \\
80\end{array}$ & $\begin{array}{c}108 / 70 \\
80\end{array}$ & $\begin{array}{c}102 / 68 \\
80\end{array}$ & $\begin{array}{l}78 / 56 \\
80\end{array}$ & $\begin{array}{l}66 / 48 \\
82\end{array}$ & $\begin{array}{l}62 / 44 \\
74\end{array}$ & $61 / 42$ & $\begin{array}{l}80 / 60 \\
68\end{array}$ & $\begin{array}{c}100 / 80 \\
68\end{array}$ & $\begin{array}{c}100 / 80 \\
68\end{array}$ & $100 / 80$ \\
\hline 12 & E. H. & 33 & $\mathbf{F}$ & $117 / 65$ & $\begin{array}{c}128 / 62 \\
70\end{array}$ & & $\begin{array}{c}113 / 69 \\
74\end{array}$ & $\begin{array}{c}96 / 49 \\
80\end{array}$ & $\begin{array}{l}96 / 54 \\
92\end{array}$ & $\begin{array}{c}100 / 53 \\
90\end{array}$ & $\begin{array}{l}92 / 55 \\
90\end{array}$ & $\begin{array}{l}99 / 61 \\
90\end{array}$ & $\begin{array}{c}115 / 69 \\
90\end{array}$ & $\begin{array}{c}110 / 69 \\
88\end{array}$ & $\begin{array}{c}118 / 71 \\
80\end{array}$ \\
\hline
\end{tabular}

jects $7,9,10,11$ and 12 and rose in Subject 8. During period III, FFA levels increased sharply in all (Figure 2). Blood pressure levels fell in all during period II, and by the completion of period III the blood pressure levels had returned to the period I levels. Heart rate increased during period II. Blood sugar levels did not appreciably change during periods I, II or III.

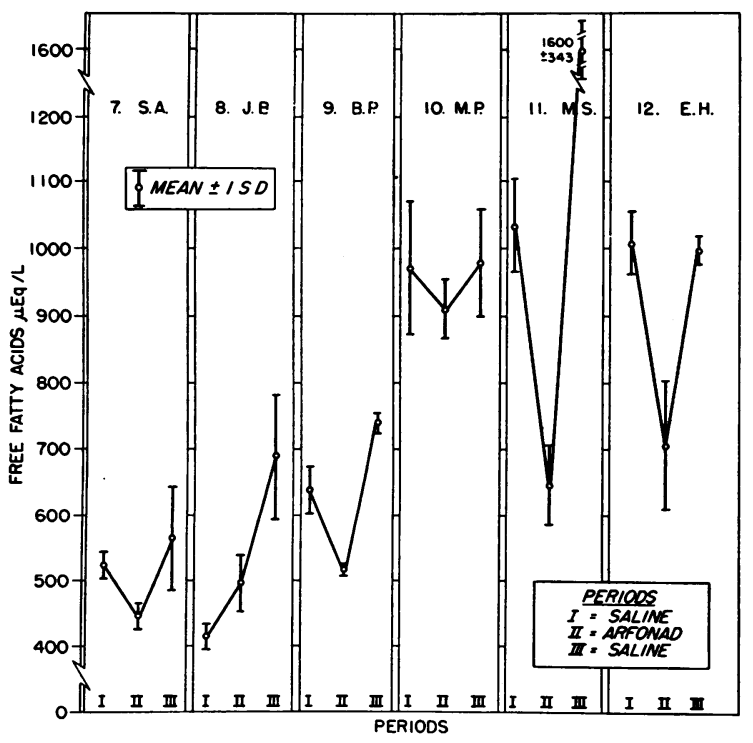

Fig. 2. Free fatty acid levels in the Six SUbJects IN WHOM AUTONOMIC GANGLIONIC BLOCKADE WAS PRODUCED BY ARFONAD INFUSION.
Arousal assessment was noted as "minimal" in periods I and II for Subject 8; "moderate" in period III for Subject 8 and in periods I through III for Subjects 7, 9 and 10. Arousal was considered to be "marked" in periods I through III for Subjects 11 and 12.

Analysis of variance of $F F A$ results. An analysis of variance (9) of the FFA levels of both the saline and Arfonad infusion groups permits the following conclusions. 1) For the saline group there were significant individual differences between the subjects and the individual subject's pattern of FFA elevation during the course of the experiment $(p=<0.05)$. 2) The increase in the FFA levels that occurred during the course of the morning was significant $(\mathrm{p}=<0.001)$.

For the Arfonad group: 1) The magnitude of the response during ganglionic blockade was significantly different between individual subjects $(p=<0.001)$. 2) The FFA level fell significantly during ganglionic blockade (period II; $\mathrm{p}=<0.001)$.

Effect of ganglionic blockade upon response to threatening stimuli. Figure 3 illustrates the pattern of FFA levels observed in a 21 year old white male who demonstrated signs suggestive of marked autonomic nervous system activation when a needle was placed in an artery. The signs included striking sweating of the palms and forehead 


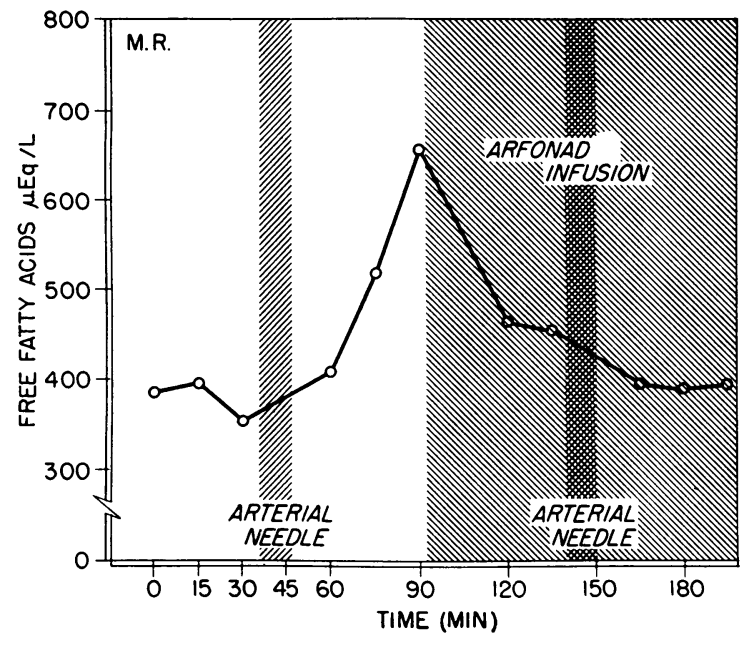

Fig. 3. Free fatty acid LeVel in aN IN INIVIdul PRESENTED WITH A THREATENING STIMULUS BOTH BEFORE AND DURING AUTONOMIC GANGLIONIC BLOCKADE.

(the sweat literally pooled in his palm), pallor of the face, dilatation of the pupils and much grimacing and writhing. The needle site on both occasions was thoroughly infiltrated with a local anesthetic. The subject did not report any pain but merely stated: "I cannot stand needles." During the infusion of Arfonad and when ganglionic blockade was thought to have been established, he once again was presented with an attempted arterial needle puncture. As on the first occasion he grimaced and writhed on the bed, there was some slight sweating, but very much less than previously, and facial pallor did not occur. FFA levels did not rise after the second needle attempt. This type of observation has been made in two other subjects who were also "needle reactors" (Group 3 subjects; Table II).

\section{DISCUSSION}

The sustained rise in serum FFA levels during a prolonged period of a morning fast has been previously observed (1). The pattern of rise in the saline series is consistent with these previous reports. The changes from period I to period III are statistically significant, as mentioned above. However, there are important individual differences, both in the initial period I FFA levels and in the magnitude of change that occurs during the morning of fasting. A consideration of the factors that might be responsible for these individual differences has been made. No correlation appears to exist with body height, weight, age, sex, blood sugar, heart rate or blood pressure. The assessment of arousal-although relatively imprecise-does provide, however, a possible basis for the individual differences. Previous observations have indicated that the discussion of emotionally meaningful topics is accompanied by marked rises in serum FFA levels (5) and that during participation in a challenging situation, sharp rises are also observed $(6,7)$. Table III lists the arousal assessment and the mean change for the FFA levels between periods I and II and periods II and III for the subjects of the saline infusion group. The arousal assessment assigned for these comparisons relates to the latter period of each pair. Statistical analysis of the changes during the two types of arousal-rated periods indicates a significant difference $(p=<0.01)$, the greater FFA rises occurring in individuals who were rated as being more aroused. This correlation between individual variability of these "resting" saline infusion studies and the assessment of arousal further supports the pertinence of central nervous system activity to FFA metabolism and may also apply to the analysis of the individual differences of the ganglionic blockade studies. In five of six of these subjects during blockade there was a marked decrease in the FFA levels, but as was mentioned above, the magnitude of the individual responses was significantly different. Here again, an attempt to correlate some other factor with the degree of FFA change re-

TABLE II

Free fatty acid levels in response to threatening stimuli with and without autonomic ganglionic blockade

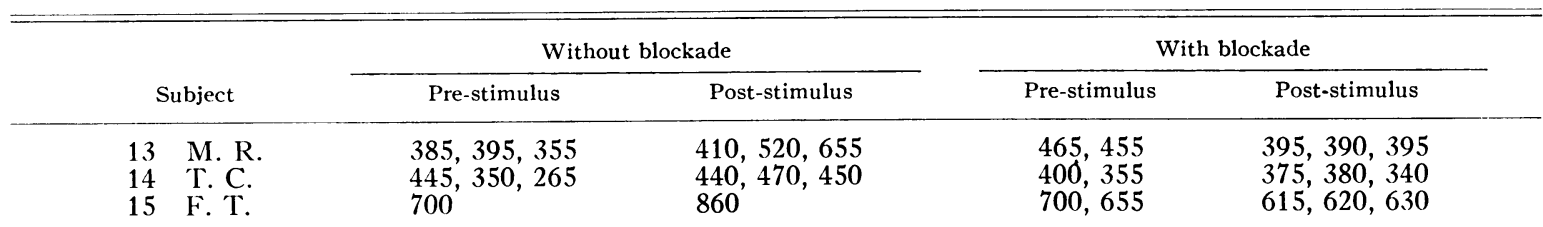


TABLE III

Change in serum free fatty acid (FFA) in individuals receiving normal saline infusions rated according to degree of arousal

\begin{tabular}{|c|c|c|c|c|c|}
\hline \multicolumn{3}{|c|}{ Minimally aroused* } & \multicolumn{3}{|c|}{ Moderately aroused } \\
\hline Subject & Period & $\triangle \mathrm{FFA}$ & Subject & Period & $\triangle \mathrm{FFA}$ \\
\hline $\begin{array}{l}1 \\
1 \\
2 \\
2 \\
3 \\
6\end{array}$ & $\begin{array}{c}\text { I-II } \\
\text { II-I I I } \\
\text { I-I I } \\
\text { II-III } \\
\text { I-II } \\
\text { I-II }\end{array}$ & $\begin{array}{c}\mu E q / L \\
+86 \\
-31 \\
+21 \\
+81 \\
-2 \\
+9\end{array}$ & $\begin{array}{l}3 \\
4 \\
4 \\
5 \\
5 \\
6\end{array}$ & $\begin{array}{c}\text { II-III } \\
\text { I-II } \\
\text { II-III } \\
\text { I-II } \\
\text { II-III } \\
\text { II-III }\end{array}$ & $\begin{array}{r}\mu E q / L \\
+309 \\
+182 \\
+115 \\
+90 \\
+142 \\
+162\end{array}$ \\
\hline \multicolumn{2}{|c|}{$\begin{array}{l}\text { Mean } \\
\text { SE }\end{array}$} & $\begin{array}{l}+27 \\
\pm 3.6\end{array}$ & & $<0.01$ & $\begin{array}{l}+166 \\
\pm 4.7\end{array}$ \\
\hline
\end{tabular}

* Arousal assessment refers to the category assigned to the latter period (II in I-II differences, III in II-III differences).

sulted in noting an association with the arousal assessment. Subjects 11 and 12 were strikingly aroused during the course of the study, and they demonstrated the most marked decrement in FFA level during ganglionic blockade. These individuals also had higher period I initial values. Subject 8, who was rated as "minimally" aroused, demonstrated an increase rather than a decrease. In the others - 7,9 and 10, rated as "moderately" aroused-initial values were at a midpoint between Subjects 8, 11 and 12, and the magnitude of FFA level decrease during Arfonad infusion in these individuals was less than in the markedly aroused subjects (Table IV).

We have therefore proposed the formulation that in the individuals in whom arousal was more marked, the contribution of autonomic nervous system activity to FFA level was probably greater; thus, during inhibition of autonomic activity by the ganglionic blocking substance, the magnitude of FFA fall would be greatest in those individuals. Conversely, when little or no arousal was present, then autonomic blockade would effect little or no

TABLE IV

Change in serum free fatty acid in individuals during ganglionic blockade rated according to degree of arousal

\begin{tabular}{|c|c|c|c|c|}
\hline $\begin{array}{l}\text { Minimal } \\
\text { arousal }\end{array}$ & \multicolumn{2}{|c|}{$\begin{array}{c}\text { Moderate } \\
\text { arousal }\end{array}$} & \multicolumn{2}{|c|}{$\begin{array}{l}\text { Marked } \\
\text { arousal }\end{array}$} \\
\hline Subj. $8+81$ & $\begin{array}{l}\text { Subj. } \\
1\end{array}$ & $\begin{array}{rr}7 & -75 \\
9 & -123 \\
10 & -63\end{array}$ & $\begin{array}{r}\text { Subj. } 11 \\
12\end{array}$ & $\begin{array}{l}-392 \\
-301\end{array}$ \\
\hline
\end{tabular}

change in FFA level, as was the case in Subject 8 .

We feel, therefore, that the decrease in serum FFA levels during ganglionic blockade in the resting subject appears to support the thesis that activity of the autonomic nervous system is influencing to some extent the dynamic "steady" state of FFA metabolism.

The importance of nervous system activity to lipid metabolism has been recognized since the initial studies of Wertheimer (10) demonstrated that spinal cord section at the level of T2-3 would modify the fatty infiltration of the liver that accompanied phloridzin diabetes. Beznak and Hasch (11) observed that splanchnic nerve section, stellate and superior cervical ganglionectomy, and lumbar and sacral ganglionectomy markedly reduced fat deposition and mobilization on the denervated side compared with the intact side of the animal. Clément's studies $(12,13)$ confirmed and extended these observations. Hausberger (14) and then later Sidman and Fawcett (15) demonstrated that section of the regional nerves supplying the dorsal interscapular fat pads of mice and rabbits resulted in a decrease in the mobility of the fat of these tissues. Butler, Maling, Highman and Brodie (16) most recently reported that several autonomic nervous system blocking agents (Dibenamine, Dibenzylin, and ergotamine) modified the fatty infiltration of the liver in rats treated with carbon tetrachloride, ethanol, and ethiomine. A similar series of studies has also been reported by Calvert and Brody (17). These reports all suggest that the autonomic division of the nervous system plays a role in lipid metabolism but at just what site or through what mediating substances is not known.

Havel and Goldfien have recently reported (2) that the administration of hexamethonium ( $5 \mathrm{mg}$ per $\mathrm{kg}$ ) reduced serum FFA levels in the dog. Measurements of serum FFA and serum FFA specific activity during concurrent administration of tracer doses of albumin-bound palmitic acid $1-\mathrm{C}^{14}$ and of hexamethonium indicate that hexamethonium decreases FFA inflow to the plasma. It was also reported that "anxiety or discomfort" in man and "decreasing depth of anesthesia" in the dog were accompanied by a rise in FFA concentration and that the rise in FFA in the dog was blocked by hexamethonium. 
The studies reported here do not specifically distinguish the basis for the fall in FFA levels during ganglionic blockade as being either a decrease in FFA mobilization from fat depots or an increase in tissue utilization. Since there was no evidence of increased metabolism during the infusion-the subjects remaining at rest throughout and blood sugars being constant throughout-it would appear that a decrease occurred in release of FFA from adipose tissue into the serum rather than in an increase in FFA utilization. The inhibition by ganglionic blockade of the rise in FFA levels that usually follows threatening experiences in the human subject is of particular interest. In these situations the organism is aroused and metabolism is increased, the net rise in serum level reflecting a mobilization of FFA from adipose tissue. The failure of these rises to occur during emotional arousal in the presence of ganglionic blockade would tend to support the thesis that FFA inflow into the plasma is blocked during pharmacological suppression of autonomic activity.

It is our conclusion, therefore, that the autonomic nervous system provides a stimulatory component to lipid mobilization and that the mechanism is operative in both the resting and aroused individual.

\section{SUM MARY}

1. Serum free fatty acid levels were followed before, during and after infusion of saline into six subjects; and of Arfonad (trimethaphan camphorsulfonate), a rapidly-metabolized ganglionic blocking agent, into six subjects. In three other individuals, free fatty acid (FFA) response to a threatening stimulus was observed both with and without ganglionic blockade.

2. During saline infusion there was a gradual and sustained rise in FFA levels. Blood pressure increased also during this time. Heart rate remained relatively steady and blood sugar did not change.

3. In five of the six subjects in whom ganglionic blockade was established, FFA levels fell during the course of the blockade. Immediately following the blockade, FFA levels rose sharply in all subjects. In all subjects during blockade, blood pressure decreased and pulse rate increased. The blood sugar remained unchanged.
4. Ganglionic blockade inhibited the rise of FFA levels that follows presentation of a threatening stimulus.

5. These studies are believed to support the thesis that the autonomic nervous system contributes a stimulatory component to the mobilization of free fatty acids from adlipose tissue.

\section{ACKNOWLEDGMENTS}

We wish to express our appreciation to Dr. David M. Shaw of the Department of Sociology for his aid in performing the statistical analysis, and to Dr. J. Campbell Howard of Roche Laboratories for the generous supply of Arfonad.

\section{REFERENCES}

1. Dole, V. P. A relation between non-esterified fatty acids in plasma and the metabolism of glucose. J. clin. Invest. 1956, 35, 150.

2. Havel, R. J., and Goldfien, A. The role of the sympathetic nervous system in the metabolism of free fatty acids. J. Lip. Res. 1959, 1, 102.

3. Gordon, R. S., Jr., and Cherkes, A. Production of unesterified fatty acids from isolated rat adipose tissue incubated in itro. Proc. Soc. exp. Biol. (N. Y.) 1958, 97, 150.

4. White, J. E., and Engel, F. L. The lipolytic action of epinephrine and norepinephrine on rat adipose tissue in vitro. Proc. Soc. exp. Biol. (N. Y.) 1958, 99, 375.

5. Bogdonoff, M. D., Estes, E. H., Jr., and Trout, D. Acute effect of psychologic stimuli upon plasma non-esterified fatty acid level. Proc. Soc. exp. Biol. ( N. Y.) 1959, 100, 503.

6. Cardon, P. V., Jr., and Gordon, R. S., Jr. Rapid increase of plasma unesterified fatty acids in man during fear. J. psychosom. Res. 1959, 4, 5.

7. Bogdonoff, M. D., Harlan, W. R., Trout, D. L., Kirshner, N., and Estes, E. H., Jr. Observations on serum free fatty acids, glucose, heart rate, blood pressure, and urinary excretion of catechol amines during a state of acute central nervous system arousal. J. clin. Endocr. In press.

8. Nelson, N. A photometric adaptation of the Somogyi method for the determination of glucose. J. biol. Chem. 1944, 153, 375.

9. McNemar, Q. Psychological Statistics, 2nd ed. New York, John Wiley, 1955.

10. Wertheimer, E. Stoffwechselregulationem. Regulation des Fettstoffwechsels. Die zentrale Regulierung der Fettmobilisierung. Pflüg. Arch. ges. Physiol. 1926, 213, 262.

11. Beznak, A., and Hasch, Z. The effect of sympathectomy on the fatty deposit in connective tissue. Quart. J. exp. Physiol. 1937, 27, 1. 
12. Clément, G. Etude physiologique comparée de la mobilisation des graisses au cours du jeûne sur deux types de tissue adipeux de réserve. C. $R$. Soc. Biol. (Paris) 1947, 141, 255.

13. Clément, G. Démonstration directe de l'effet mobilisateur des hormones hypophysaires sur les graisses de réserve. Rôle du système nerveux sympathique. C. R. Soc. Biol. (Paris) 1947, 141, 317.

14. Hausberger, F. Über die nervöse Regulation des Fettstoff wechsels. Klin. Wschr. 1935, 14, 77.
15. Sidman, R. L., and Fawcett, D. W. The effect of peripheral nerve section on some metabolic responses of brown adipose tissue in mice. Anat. Rec. 1954, 118, 487.

16. Butler, W. M., Jr., Maling, H. M., Highman, B., and Brodie, B. B. Deposition of liver triglycerides by various agents and its prevention by adrenergic blocking agents. Fed. Proc. 1959, 18, 374.

17. Calvert, D. N., and Brody, T. M. Mechanism of hepatotoxicity of carbon tetrachloride. Fed. Proc. 1959, 18, 375. 